\title{
The Muslims' Quest for a Kalmunai Administrative District in South-Eastern Sri Lanka: An Analysis of the Challenges from Their Community and Politics
}

\author{
Mohammad Agus Yusoff ${ }^{1} \&$ Athambawa Sarjoon ${ }^{1,2}$ \\ ${ }^{1}$ School of History, Politics and Strategic Studies, Faculty of Social Sciences and Humanities, Universiti \\ Kebangsaan Malaysia, UKM Bangi 43600, Selangor, Malaysia \\ ${ }^{2}$ Department of Political Science, University of Peradeniya, Peradeniya-20400, Sri Lanka \\ Correspondence: Mohammad Agus Yusoff, School of History, Politics and Strategic Studies, Faculty of Social \\ Sciences and Humanities, Universiti Kebangsaan Malaysia, UKM Bangi 43600, Selangor, Malaysia. Tel: \\ 60-19-338-0962. E-mail: agus_ukm@yahoo.com
}

Received: June 22, 2016 Accepted: July 26, 2016 Online Published: October 30, 2016

doi:10.5539/jpl.v9n9p55 URL: http://dx.doi.org/10.5539/jpl.v9n9p55

\begin{abstract}
The Muslim community living in the "South-Eastern Region" of Sri Lanka has long been urging the government authorities to establish a separate Kalmunai administrative district carved out of the coastal belt of the present Amparai district, as an institutional mechanism to improve public service delivery and development administration functions in the region. However, the establishment of the Kalmunai administrative district has continually been challenged, receiving criticism and oppositions from different sources, including from the Muslim community and its politicians. This study analyzes the perspectives of Muslim community and its politics towards the demand for the Kalmunai administrative district and its impacts on the political advocacy and methods to achieving it. This study has found that there are different and contradictory perspectives on the matter of the Kalmunai administrative district among the Muslim political parties and in different segments of the community. It is also discovered that the public understanding on the subject of the proposed district is very minimal. The establishment of the proposed Kalmunai administrative district has frequently failed on many crucial occasions mainly due to the lack of consensus among the Muslims leaders regarding the contested subjects of the proposed district. Additionally, this study has observed that the Muslim leaders have conceptualized the proposed Kalmunai district purely based on ethnicity only and have failed to justify it on public and rational grounds. The study has further found that the establishment of the proposed Kalmunai administrative district and its purported positive impacts would strongly depend on making the demand for the proposed district a more secular and public one.
\end{abstract}

Keywords: Sri Lanka, Muslim community, Kalmunai administrative district, oppositions and challenges

\section{Introduction}

The Muslim concentration in the South-eastern region plays a vital role in Sri Lanka's Muslim and national politics, as this region forms the heartland of the Muslims politics. It is the only region where the Muslims form the absolute majority (68.6\%) in regional population. The core supporters of the Sri Lanka Muslim Congress (SLMC), the main successful Muslim political party in the country, are from this region. However, since the region is part of the Amparai district, it has continued to suffer in terms of public service delivery, regional development, and resource utilization (such as land and water) due to the partial and discriminatory nature of the district administration, which is entirely controlled by the Sinhalese (Ibrahim, 2002; Mohideen, 2013; Sarjoon et al., 2015 \& Yusoff et al., 2015). Although the region makes up of more than 65 percent of the Amparai district population, and most of them are Tamil-speakers, the district administration is dominated by Sinhalese administrators and continued to functions in Sinhala language, which has resulted in the administrator marginalizing the due rights and interests of Tamil-speaking communities in the district administration. These factors have motivated the people of this region to demand for a separate administrative mechanism for this region through the establishment of a new administrative district popularly referred to as "Kalmunai." The people and politicians of the region have been advocating the establishment of this proposed district for the last 
50 years. However, following the intense ethnic conflict and civil war and its ethno-centric impacts, the Muslim community and the major Muslim political party that represents them, the SLMC, have advocated for the establishment of the proposed administrative district for the last 3 decades. However, the Kalmunai administrative district demand has only begun to receive political importance in the last 15 years.

The proposed Kalmunai administrative district forms a territory of 1867.7 sq.km covering 14 divisional administrative units (Divisional Secretariats-DS) that come under the 3 electorates of Sammanthurai, Kalmunai, and Puttuvil in the present Amparai district. The proposed district has a population of 409,260, which is equal to 63 percent of the total population of Amparai district, according to the 2012 census. Among them, the Muslims constitute $68.60 \%$; the Tamils make up $27.40 \%$, while the Sinhalese constitute $3.5 \%$ (Department of Census and Statistics, 2014). This region is popularly known for its contribution to the country's paddy production. Accordingly, the Amparai district contributes about 20 percent of the country's paddy production and about 70 percent of the paddy yield in the 2011 Yala season in the Amparai district was from this region (District Secretariat, Amparai, 2013). Apart from paddy cultivation, the region also has good potential in the fishing, agricultural, and marine-cum-heritage-based tourism industries (See: Yusoff et al., 2016).

The Tamils and the Muslims of the region, under the common banner of "Tamil-speakers", were the first to advocate for the Kalmunai administrative district collectively even before the establishment of the present Amparai district. However, with the intense civil war in the middle of 1980s and following its impact on the Muslim community in the region, the Muslims became the main advocates for this agenda, receiving criticisms and oppositions from other ethnic groups. The SLMC has put forward this demand as one of its major political demands in the political platform for the last 3 decades. Also, this demand has been accommodated for in many political agreements reached between the SLMC and major political parties, and treated as a priority subject in their bargaining politics. However, up until now, the Muslim politicians have failed to fulfill this demand even though there have been many occasions for them to do so. On the other hand, this demand has received huge criticisms and oppositions not only from other ethnic groups and political forces, but also from the Muslim community and Muslim politics itself. It was found that the public understanding on the subject of the Kalmunai administrative district demand, especially among the Muslim community of the region, is also very limited. All these issues have undermined the feasibility of realizing this demand to a certain extent. Given this backdrop, this study aims to extensively examine the oppositions and challenges emerged from the Muslim community and Muslim Politics in regard to the demand for the Kalmunai administrative district. The major objective of this study is to analyze the criticisms, oppositions, and challenges that have been posed by the Muslim community and the community's politics in the process of advocating for the Kalmunai administrative district, together with their associated impacts.

\section{Materials and Methods}

This study is part of a 3-year research project, which extensively analyzed the demand for the Kalmunai administrative district. This study has adopted both primary and the secondary data collected from different sources. The primary data was mainly collected from interviews (elites and semi-structures), focus group discussions, and participant observation. About 45 informants were chosen from different categories (such as national and local politicians, academics, journalists, civil activists, and the general public) as interviewees. Three focus group discussions were conducted among the three major ethnic groups living in the proposed district i.e. Muslims, Tamils, and Sinhalese. The primary data was also collected from participant observation via field visits to the District Secretariat (Amparai), and Divisional Secretariats in the research area. Academic journal articles, books, research publications, government reports, and newspaper articles were the major secondary sources used in this study. Both the primary and secondary data are presented in this paper in the form of direct quotations, summaries, and interpretive explanations and arguments.

\section{Major Findings - The Nature of the Muslim Advocacy of the Kalmunai Administrative District, and the Oppositions and Challenges from the Muslim Community and Muslim Political Forces}

The demand calling for the establishment of the Kalmunai administrative district for the coastal belt in Amparai, its advocacy, and its fulfilment, has also been challenged in the form of criticisms and oppositions expressed by the Muslim political forces and the Muslim community, similar to other oppositions [Note 1]. These oppositions and challenges have also influenced the opportunities for establishing the proposed district in the past. The following sub-sections analyze these arguments in detail.

\subsection{One-party Centered Demand and Lack of Support from Other Political Forces (Fragmentation of Muslim Politics)}

One of the major factors that challenged the advocacy and fulfillment of the demand for the Kalmunai 
administrative district is the lack of political support from the political forces of the Muslim community. The proposed Kalmunai district has mainly been advocated by a single Muslim political party throughout the history of it advocacy, whereas the other Muslim parties have only criticized and opposed it. Although the demand for this district started before the establishment of the SLMC, the SLMC and its leaders have seriously taken it up and have since advocated the cause on societal and political grounds. Up until now, the SLMC is the one and only major political force that has strongly been supporting and advocating the establishment of the Kalmunai administrative district. All other Muslim political parties including the parties that have emerged from the split in the SLMC have been mostly non-supportive or have remained silent whenever the subject becomes the forefront of political debate and discourse, besides receiving criticisms and opposition from other ethnic groups and political forces. This study has found that the initiatives of the United National Party (UNP) government to establish the proposed Kalmunai district in the middle of 1980s was seriously opposed not only by the Sinhalese parliamentarians of the Amparai district but also by the Muslim parliamentarians of the district who represented the UNP, of whom were strong critics of the idea and the demands of the SLMC (Noorul Haque, 2002).

In terms of political survival within the Muslim community, there is no other stronger political and social force that is advocating for the establishment of Kalmunai administrative district besides the SLMC. Whenever the SLMC advocates for this Kalmunai district, the majority of the Muslim leaders representing the other political parties would keep silent or avoid expressing their support. The initiatives of President Kumaratunga in 2000 to form the Kalmunai administrative district was abandoned partly due to the fragmentation among the leaders of SLMC, which resulted in the formation of two wings within the party-the Rauff Hakeem wing and the Ferial Ashraff wing - the members of the latter opposed Hakeem's 100-day demand, which was the initial political demand for establishing the Kalmunai district, put forward to the PA government in 2000 (See: Deshavimala, $2001 \&$ Subramanian, 2001).

It is worth noting that the political parties that emerged from the split in SLMC after the demise of its founder leader, Ashraff, in 2000, have also continued to oppose or avoided expressing their open support for the Kalmunai administrative district. In 2003, the effort of the United National Front (UNF) to establish the proposed Kalmunai district was abandoned mainly due to the lack of consensus between the leaders of the SLMC and the one-man National Congress (NC), headed by A.L.M.Athaullah - a party that had just emerged from the split in the SLMC in that same year-on the matter of naming the proposed district and placing its Secretariat. The SLMC leaders proposed "Kalmunai" as the name for the district and that its secretariat also be established in Kalmunai, a first municipality but located in the north end of the proposed district. However, Athaullah, also a minister in the UNF government, argued that "Akkaraippatthu," a town in the middle of the north-south distance of the proposed district, should be named the capital of the district instead. Since no compromise could be reached between both leaders, the UNF government simply abandoned the initiative (Skybetbit.com, 2005).

When the SLMC representatives picked up the cause and again urged the government authorities to establish the Kalmunai administrative district in the 2015 budget debate in the parliament, they received huge criticisms and opposition from the government and the opposition wings in parliament, and none of the major Muslim parties with representations in the parliament expressed their support for the SLMC representatives and the establishment of Kalmunai district. Only at the last stage of the 2015 parliamentary election did Rishad Bathiudeen, the leader of the ACMC — another Muslim party that emerged from the split in the SLMC-reported that his party would not ally with the next government and their representatives would not take any ministerial responsibility until the Prime Minister of the new government declared the establishment of the proposed Kalmunai district, on the condition that the Muslims of the Amparai district voted for his party to secure two seats in the election (Courierboys.com, 2015). This challenge was made only after his party decided to contest in the Amparai district and when the on-ground reality seemed to favor them and it looked like they would be able to win a seat in the district. Therefore, this challenge was viewed as an electoral strategy to attract more Muslim voters from the district.

\subsection{SLMC Leaders Failed to Utilize the Opportunities to Realize the Establishment of the District}

It was also found that the leaders of the SLMC have failed to justify the establishment of the proposed district on rational ground at national-level politics and have not been able to push the government authorities to establish the proposed district through political bargaining. The SLMC leaders and supporters proudly claim that their founder leader, M.H.M.Ashraff, has voiced and advocated for the rights and interests of the Muslim community in Sri Lanka, but no recorded speech or document is publicly available within or outside the Parliament as evidence that Ashraff had strongly advocated for the importance and necessity of establishing the Kalmunai administrative district. On the other hand, Ashraff faced some crucial occasions in which he could have pushed 
the Kalmunai district demand and succeeded in establishing the district during his career, but he failed to make use of any of these opportunities.

M.H.M.Ashraff had played a vital role in politicizing Muslim concerns and grievances nationally and internationally during his political career. He played a dynamic role in national politics from 1989 to 2000, initially as an opposition member of the parliament (1989-1994) and then as an influential coalition partner in the People's Alliance (PA) government (1994-2000). He gained political popularity when his party became the third major political force in the country after the provincial council elections held in November 1988, just one month before the Presidential election. During the 1988 Presidential election, there had been voices against the UNP rule and for a political change in the country. Therefore, the UNP presidential candidate and the then Prime Minister, Ranasinghe Premadasa, called for the electoral support of the SLMC. However, Ashraff extended the support of his party with the condition that the cut-off vote in the proportional representation system that conditioned a political party or group be qualified for district representation at the Parliamentary election be reduced. Following Premadasa's acceptance of the condition, which was fulfilled through the Fifteenth Amendment of the constitution and certified on 17 December 1988, just two days before the election, the SLMC leaders propagated to vote Muslims for the UNP candidate [Note 2].

During Ashraff's first tenure in parliament (1989-1994), although the UNP government had two-thirds majority in parliament, he unofficially supported the initiatives of the government and President Premadasa. In fact, his support was crucial importance for the president at that time for his political survival. Through his unofficial support, not only did Ashraff bring benefits to his community but he also strengthened the position of President Premadasa. Until the impeachment motion put forward against President Premadasa in parliament in August 1991, Premadasa's government enjoyed two-thirds majority in the parliament. Premadasa was compelled to beg for the support of the SLMC during this period; he and his cabinet were ready to fulfill any kind of request from Ashraff. During this period, Ashraff could have put forward the Kalmunai district demand before President Premadasa. However, no records show that Ashraff actually attempted to do so. Although Premadasa's government had two-thirds majority in the parliament, which is mandatory for any changes or alteration in the constitution, Ashraff failed to put forth and realize the Kalmunai administrative district demand during this period.

Similar to Ashraff, from 2010 and 2015, the present national leader of the SLMC, Rauff Hakeem, has also failed to utilize two important opportunities presented to him to realize the Kalmunai administrative district. In 2010, President Mahinda Rajapaksa pleaded for the goodwill of the SLMC in order to secure the two-thirds majority in parliament necessary to pass the Eighteenth Amendment of the constitution, which would change the provision for a President in which if he/she was elected, he/she could serve any number of terms; the previous provisions were limited to only two six-year terms (See: Parliament Secretariat 2011). President Rajapaksa wanted to remain in power but he lacked with six more members to secure the two-thirds majority to pass the Eighteenth Amendment, therefore, he would have given any prize to win the support of the SLMC members in parliament. The move towards this new constitutional amendment was seen as an extremely controversial one with deep political implications, and hence received a lot of criticism. In the end, however, the SLMC gave their full support for this constitutional amendment without putting forth any conditions or gaining any benefit from a quid pro quo agreement for the support; even more so considering that they were on the opposition wing. The SLMC leader could have used this opportunity to include the matter of the Kalmunai district as a condition to offer the party's support for the Eighteenth Amendment, but again, similar to his predecessor, he failed to use this opportunity.

In 2012, after the eastern provincial council election, the United People Freedom Alliance (UPFA), headed by President Mahinda Rajapaksa, wanted to remain in power in the eastern province to show his political support in the eastern province to the international community. Furthermore, strategically having control over the eastern province was important for the government to further undermine the autonomous and separatist demands of the minorities in Sri Lanka. Therefore, President Rajapaksa was compelled to again beg for the support of the SLMC to form the provincial government of his party since no other party would gain the majority after the election. The Muslim community voiced out their worries and agitations to the SLMC leaders over the Rajapaksa regime's continuous negligence in establishing the Kalmunai administrative district as had been promised before. Therefore, the SLMC leader could have used this opportunity to push the government to declare and establish the Kalmunai administrative district before extending the party's support for the UPFA to form the provincial government, or even convince the UPFA to sign an agreement in this regard. The SLMC leader failed to do both, and gave his unconditional support to the UPFA to form the provincial government.

There are different viewpoints and arguments regarding the lack of advocacy and failure of the SLMC leaders to 
capitalize on the opportunities to advance the matter of Kalmunai administrative district and to establish it. Some criticize that the thought of the Kalmunai administrative district never crossed Ashraff's mind, as he had no idea about it. Therefore, he did not involve himself much in the political discourse of the matter nor tried to realize it though the political strength of his party or his bargaining politics. Advocates of this line of argument reveal that Ashraff had mainly focused on gaining political power and authority on his behalf and to further cement a national and international reputation for himself and his party. One such critic was the co-founder of the SLMC, Segu Issadeen, who raised an important question in this regard, "Why had Ashraff failed to put forward this demand while he was active and influential in politics from 1989 to 2000, although he was supporting the central government on crucial junctures when the demand was at its peak?" (Segu Issadeen, Personal communication, 28 August, 2014). This question, although rational to a certain extent, has not yet been properly answered by any of the SLMC leaders.

However, this study has found that the political context of Ashraff's period was one of the factors that influenced Ashraff's choice and theme of political discourse and demands. When Ashraff started his active political career through the SLMC in 1986, the ethnic conflict and civil war were at their peak. Therefore, ethnic politics was part and parcel of each ethnic group in Sri Lanka. On the other hand, the ethnic conflict and civil war had also impacted the entire life of the north-eastern Muslims, an ethnic minority that had never been involved in a separatist struggle and war with any ethnic groups or against government forces in Sri Lanka. Therefore, when these affected Muslims started to search for a political-institutional mechanism to safeguard them, Ashraff expressed his support for them through his political party and using the power it had gained (Jezeel, Personal communication, 3 September, 2014). Therefore, at that time, Ashraff was very much an advocate of the Muslim-majority political autonomy unit in the newly merged north-eastern province. Journalist and civil activists Noorul Haque (Personal communication, 3 August, 2014) also argued that Ashraff may have thought that all the administrative issues would be resolved if the Muslims gained political autonomy and control over their predominant settlements. This argument became the rational for Ashraff's actions to a certain extent since many Sinhalese expressed that Ashraff had been controlling the entire political and administrative affairs of the Amparai district during his chairmanship of the District Coordinating Committee (DCC) in Amparai from 1944 to 2000. During this period, Ashraff was able to control, to a certain extent, the government's activities of seizing Muslims' lands in the coastal belt of Amparai district in the name of historic holy centers, especially in the Deegawaapi area.

However, the case of Rauff Hakeem differs from Ashraff. During the Ashraff era, there were no more severe oppositions and criticisms within the SLMC or within the Muslim community in regard to the Kalmunai administrative district demand. However, under Hakeem's leadership, the Kalmunai administrative district demand received huge criticisms and oppositions from different sources including within the SLMC and the Muslim community. Many SLMC leaders split and left the party and criticized and opposed many of the fundamental aspects of the SLMC, including the particular Kalmunai district matter from 2000 onward, immediately after the demise of SLMCs' founder leader, Ashraff. The SLMC leaders were not able to unite these splinter groups to achieve their demands or build consensus among themselves on the subject of this district. Furthermore, the SLMC leaders were not even able to build consensus among the Muslim leaders representing the other parties on the subjects of the proposed administrative district. All these internal fragmentations of Muslim politics and the external oppositions have undermined the advocacy of the Kalmunai district and hindered any opportunities to make it a reality.

\subsection{The Conflict and Debate among the SLMC Leaders Regarding the Kalmunai Administrative District}

This study has found that there are different and conflicting views and arguments on the subject of the proposed Kalmunai administrative district among the leaders of the SLMC, the major political party that is advocating for the establishment of the Kalmunai administrative district. SLMC's present leader, Rauff Hakeem, was able to accommodate this demand in many electoral agreements with the major political parties in Sri Lanka, but he has been involved purely in the political discourses of the demand. He has also not made any strong speeches to justify and advocate the establishment of the Kalmunai administrative district in public or at the parliament up until now. Even during a personal interview with him in regard to this study, he did not express any thoughtful arguments on the demand for Kalmunai district (Interviewed on 8 September, 2014). On the contrary, only the secondary level leaders have been calling for this demand in public and at the Parliament and voicing and advocating its establishment. It is further noticed that, as Sahabdeen (2015) rightly mentioned, a number of SLMC's founder members and strong supporters have also argued and debated with the party leader on many occasions for further clarifications about the demand. In September 2014, the Chairman of the party, Baseer Shegu Davood, openly reported that the coastal administrative district is not a suitable solution for the national 
problem of Sri Lankan Muslims in front of the party leader, secretary, and many other leaders, and this received huge criticisms from the Muslim community particularly living in the proposed district. However, the first-level party leaders gave no response to the speech made by Baseer Shehu Davood, while many local government bodies controlled by the SLMC passed resolutions opposing his view on the Kalmunai administrative district matter (Sahabdeen, 2015). It was also observed through the field survey that many of the SLMC leaders are unaware of the latest demographic details of the proposed district. This clearly indicates the fact that the SLMC leaders have different and contradicting viewpoints on the subject of the Kalmunai administrative district. Actually, this fragmented nature of understanding of the proposed district among the SLMC leaders has given rise to a number of challenges in the advocacy and fulfillment of the Kalmunai administrative district, among the Muslims and other groups.

It is clear that the SLMC, in its supreme governing council and in many district level meetings, has passed resolutions requesting the government authorities to form the proposed Kalmunai administrative district. The SLMC leaders have even openly requested the government to fulfill the promises made to them regarding the establishment of the Kalmunai administrative district before the presidential election in 2015. When UPFA government failed to consider their demand, the SLMC leaders left the government to extend their support to the common presidential candidate in December 2014. This decision brought about huge criticisms in regard to the demand for Kalmunai administrative district. Even though many secondary level leaders reassured the public about the strength of their claim, the SLMC's national leader, Rauff Hakeem, at last reported in a media briefing that the SLMC leaders are not demanding for the proposed Kalmunai district. The following speech made by Hakeem proves that the SLMC leader is not strongly considering the establishment of the Kalmunai administrative district.

The SLMC condemned the allegations that they are demanding a separate district or province in the east. It is actually the government that has suggested the appointment of a separate Additional District Secretary in Amparai to facilitate the Tamil-speaking majority in the coastal area of Amparai district. During the discussions with the government, it was suggested that a separate Additional District Secretary (or AGA) be appointed to resolve the administrative problems of the 96-percent Tamil-speaking population in the coastal areas of the Amparai district. As a result, the government appointed an Additional District Secretary a month ago to decentralize administration in the district. The same thing happened in the Vavuniya District, where a separate District Secretary was also appointed to facilitate the Sinhala people. However, the government is spreading false news that we are demanding a separate district (Daily Mirror, 2015).

In the above interview, Rauff Hakeem clearly states that the proposed Kalmunai district is not the SLMC's demand but was actually the government's prerogative all along. This is unbecoming of the leader of SLMC, which is a party that has strongly been advocating for the district and spearheading the inclusion of this matter in many coalition agreements with major parties for the last 15 years. Hakeem's above speech further proves his contradictory understanding and uncertain position on the matter of the Kalmunai administrative district.

\subsection{Lack of Continued Advocacy, Publicity, and Public Understanding}

This study has also identified that the lack of continued advocacy and publicity for the Kalmunai administrative district has been a major challenge to its establishment to a certain extent. The SLMC's advocacy for the Kalmunai district has been mostly "on" and "off" in nature. The history of the SLMC's electoral politics reveals that the SLMC leaders would usually use the demand as a political weapon or condition to be fulfilled mostly during elections and when making alliances and signing agreements with major political parties. However, after attaining victory at the elections, although the party received a decisive position in deciding the forming of the government i.e. the government would be formed with the ultimate support of the party, the SLMC leaders have failed to urge the government to establish the proposed district during these regimes. In fact, as many have criticized, the SLMC only uses this demand as a political weapon to forge alliances or to fulfill the aspirations of their leaders. In many potential occasions, whilst being the government's partner or as an influential political force, the SLMC leaders have failed to push the government or the rulers to establish the proposed district, as highlighted in sub-sections 3.1 and 3.2. During 2015 presidential election, this Kalmunai district demand turned into a subject of debate among the UPFA coalition parties in which the SLMC used this demand as a political weapon to support the presidential candidate. When the UPFA presidential candidate, President Mahinda Rajapaksa, refused to establish the Kalmunai administrative district, the UPFA-SLMC coalition abruptly came to an end. Soon after, the SLMC lent its support to the common opposition's presidential candidate. However, not only did the SLMC leaders extend their party's support without any compromise on the matter of the Kalmunai administrative district, they also failed to push the matter of establishing the district within the 100-day program 
of the new government formed by the UNP, after the 2015 presidential election. Similarly, the SLMC made an alliance with the UNP in the 2015 Parliamentary election, but the Kalmunai administrative district matter was not included in the electoral agreement with the UNP and none of the SLMC leaders expressed any pressing concerns about the Kalmunai administrative district during their election campaigns. The demand, which received huge criticisms from different parties and which has been strongly and repeatedly advocated by the SLMC leaders during the 2015 Presidential election, suddenly dissipated after the election.

The SLMC leaders conducted the party's national conference in March 2016 in Palamunai, a predominantly Muslim village in the proposed district that was honored by the President and the Prime Minister of the country, formed as a gratitude to the Muslim community for supporting the forming of the new regime in 2015. There were high hopes among the Muslims that, at this conference, the SLMC leaders would urge the President and the Prime Minister to consider the Kalmunai district demand and its establishment to facilitate the Tamil-speaking communities in the district administration and to facilitate the development administration functions of the region. However, the SLMC leaders did not utter a single word about the Kalmunai administrative district, which clearly proves the opportunistic nature and politics behind the SLMC's advocacy for the proposed Kalmunai district.

This study has also found that the lack of publicity and public understanding on the subject of the Kalmunai administrative district demand among the Muslims (and non-Muslims) is also another factor, which has posed challenges and obstacles at the societal and national political level when advocating the fulfillment of the Kalmunai administrative district demand. During the field survey, some members of the general public, mostly from the Muslim community from different parts of the country, were selected as interviewees and participants in the focus group discussions in order to identify their level of understanding of the subject of the Kalmunai administrative district demand, and also their perspectives. However, the majority of the interviewees was extensively unaware of the Kalmunai administrative district matter and blamed the Muslim politicians for not publicizing it enough. It was further observed that this subject was very much marginalized among the non-Muslims and Muslims in other districts, especially living in the northern and the eastern provinces. As most of the public revealed, there are no publicly available printed documents regarding the demographic and historical aspects of the proposed Kalmunai administrative district at the SLMC headquarter, "Daarussalam", which has a publication bureau and also conducts party meetings frequently. The SLMC has many branches at the national level and international wings in many countries. There are hundreds of political representatives from the party at the national, provincial, and local levels. The SLMC could have utilized all these forces to materialize and publicize the Kalmunai administrative district matter among the public, especially among the Muslim community, but it has failed in this regard.

Furthermore, up until now, neither the SLMC nor its leaders have produced any concrete piece of evidence (or document) that outlines the content of the Kalmunai district demand and the latest demographic pictures of the proposed district. No publicity has been given to the Kalmunai district either in the annual general meetings of the SLMC or in any public capacity. Similarly, the SLMC has conducted no studies and have not even offered sponsorship to researchers, experts and organizations among Muslims to explore the different aspects of the proposed Kalmunai administrative district, its impacts, and feasibility of establishing it, except a few studies that were conducted individually. The SLMC's consultation with experts and associated parties and the public on the matter of the Kalmunai administrative district is also very minimal. There are a number of higher educational institutions in the research area, including a Muslim-majority university, which was viewed as the center of Muslim nationalism and the voice for the rights and concerns of Muslims in the past. However, up until now, the SLMC has not made any consultations with the academic community of this university on the subject of this proposed district.

\subsection{Confusion between Muslim-majority Autonomy Unit and the Muslim-majority (Kalmunai) Administrative District}

This study has also found that there are confusions and contradictions among the advocates of the Kalmunai administrative district when it comes to differentiating the Kalmunai administrative district from the Muslim-majority autonomous unit proposed by the SLMC in the 1980s-during the peak of violent ethnic conflict - as a political-institutional mechanism to safeguard the existence of the Muslim community and to empower them with political autonomy. With the intensified ethnic conflict and civil war, and the break-up of the political relationship with the Tamils, the Muslims in the eastern province started to search for an alternative political institution not only to represent them at the national parliament but also to safeguard them from the impact of the ethnic conflict and civil war. The SLMC emerged in a timely context, as a powerful political party with a popular support base mainly from the "South-Eastern region" and voiced for the rights and interests of the 
Muslims, especially for those living in the north-eastern region. In its cause, the SLMC proposed a non-contiguous Muslim-majority autonomous unit in the merged north-eastern province. The particular relevance of the Muslim-majority autonomous unit in regard to the proposed Kalmunai administrative district is that the territory of the proposed administrative district would also be the heartland of the Muslim-majority autonomous unit, which would cover the major Muslim pockets in the north-eastern province under it on a non-contiguous basis similar to the Pondicherry model in south India (See: Mohideen, 2001 \& 2002; Shegu Issadeen, 2006; Sarjoon, 2011 \& Yusoff et al., 2014). Even with the changing dynamics in the whole picture of the Muslim autonomy concept and demand, the south-eastern region still remains its heartland.

Parallel to the demand for a Muslim-majority autonomous unit, the demand calling for the establishment of the Kalmunai administrative district has also been one of the core demands of the SLMC from the middle of 1980s. When the People's Alliance government (1994-2000) attempted to resolve the ethnic conflict through sharing of political powers to regionally concentrated ethnic groups with the adaptation of a new constitution, the SLMC had also submitted its proposal on subjects particularly concerning the Muslims living in the north-eastern region. Among the SLMC's recommendations, the establishment of a Kalmunai administrative district and a non-contiguous Muslim-majority autonomous unit were prominent (See: Ameerdeen, 2006; Sarjoon, 2011 \& Yusoff et al., 2014) In this way, it can be argued that the SLMC leaders had actively articulated and advocated for the Kalmunai administrative district as an alternative to the autonomous power-sharing unit for Muslims. However, the SLMC leaders have failed to distinguish between these two demands. There are still a significant number of them who find that the establishment of the proposed district would bring political autonomy to the Muslims. In the history of the post-Ashraff era (after 2000) of Muslim distinct politics, on many occasions, the SLMC leaders have pronounced and advocated for the Kalmunai administrative district, as it would be the first step to achieving a Muslim-majority autonomous unit. It was further observed that many of the leaders, representatives, and supporters of the SLMC were of the same opinion.

Similarly, many Muslims, including politicians, the academicians and the public are of the opinion that the proposed district would empower Muslim politics in a number of ways. In support of the above opinion, the SLMC's Secretary General expressed his view that the proposed district could become the power-base for Muslims in Sri Lanka, as it would empower the electoral politics of Muslims (Hassan Ali, Personal Communication, 8 August, 2014). Noorul Haque (Ibid), a senior journalist and Muslim activist, argued that the proposed district would act as the base for any kind of political power-sharing unit for Muslims in any ethnic conflict resolution process. Academics like Aliff (Personal Communication, 14 July, 2014) and Fousar (Personal communication, 22 September, 2014) also agree that the proposed district would greatly benefit Muslim politics, especially the politics of SLMC. However, it is worth noting that the expected political impacts of the Kalmunai administrative district on the Muslim community and politics strongly depends on the declaration of the proposed administrative district as an electoral district as well. According to the present electoral system, one or more administrative district could collectively be formed as an electoral district, similar to the Vanni and Jaffna electoral districts [Note 3). However, it is discovered that the SLMC leaders have not actually voiced for the declaration of Kalmunai as an electoral district, but rather as an administrative district only (See: Yusoff and Sarjoon, 2016b).

All the above-mentioned Muslim factors have posed a lot of trouble, obstacles, and challenges in the advocacy and viability of fulfilling the demand calling for the establishment of the Kalmunai administrative district in the coastal belt of the Amparai district.

\section{Concluding Remarks}

The Kalmunai administrative district demand, which was put forward at the peak of Sri Lanka's ethnic conflict and civil war by the Sri Lanka Muslim Congress (SLMC), the main Muslim political party founded by the late M.H.M.Ashraf, has received criticisms and oppositions from different sources, including from the Muslim community and Muslim politics. These oppositions and criticisms have also been influential in the advocacy process and in undermining of the feasibility of establishing the proposed Kalmunai administrative district. The SLMC is the only party that has been advocating for the establishment of the Kalmunai administrative district over the last 3 decades, with very minimal support from other Muslim political parties and political forces. This study has found that the initiative to establish the Kalmunai administrative district has frequently met with failure at the initial stage (during 1980s) due to the oppositions expressed not only by the Sinhalese politicians in the region but also by the Muslim politicians that represented the region within the government. Similarly, the study has found that although the founder-leader of the SLMC was influential in the parliament and government during his active political career, he failed to strongly advocate for and urge the rulers to establish the proposed Kalmunai administrative district. This same scenario is seen in the post-Ashraff era as well. There were a number 
of crucial occasions favoring the SLMC leaders to realize the Kalmunai administrative district demand over the last 15 years, but they have failed to fulfill this demand due to the fragmentation within the party, a lack of consultation with other ethnic groups and political parties, and due to the highly ethnicized nature of this demand. This study has also found that the advocacy for the proposed district by the Muslim parties and community follows an "on" and "off" nature, and the public understanding of the demand is also very minimal. All these factors have strongly hindered the process of establishing the Kalmunai administrative district.

This research recommends certain revisions for conceptualizing the Kalmunai administrative district as a rational and public demand that would be easily acceptable by other ethnic groups and political forces. The SLMC leaders have strongly been advocating the Kalmunai administrative district as a Muslim-majority district, arguing that there are districts for Sinhalese and Tamils, but not for Muslims. This has caused the other ethnic groups and politicians to oppose and criticize the proposed district based on communal line. Similarly, there is a high need for civic dialog and civil society activism on the subjects of the Kalmunai administrative district among the Muslim community and between other communities living in the proposed district, as well as at the national level. This process can turn the Kalmunai administrative district demand into a more rational and public one. Also, there are different and contradicting arguments on the subject of the Kalmunai administrative district and its impact on the Muslim politicians and the public, which would challenge to enhance public support for the proposed district. A consolidated effort between the politicians and civil society institutions can make the demand a more public and achievable one. Therefore, it is the responsibility of the Muslims politicians, particularly the SLMC leaders, to build consensus among the ethnic groups and major political forces on the contested subject of the proposed Kalmunai administrative district, so that they would reconsider their criticisms in the future. It is also the responsibility of the Muslim politicians and Muslim civil actors to work collectively towards justifying and advocating the Kalmunai administrative district in order to facilitate and improve the public service delivery and development administration functions of the region.

\section{References}

Ameerdeen, V. (2006). Ethnic politics of Muslims in Sri Lanka. Kandy: Center for Minority Studies.

Courierboys.com. (2015). I will accept ministerial portfolio after declared coastal district-Minister Rizad. Retrieved August 15, 2015, from http://courierboys.com/homedowndet.php?recordID=220

Daily Mirror. (2015). Hakeem rejects govt. charges. Daily Mirror. Retrieved April 24, 2015, from http://www.dailymirror.lk/60189/rejects-govt-charges\#sthash.QEJhtBnc.dpuf

Department of Census and Statistics. (2014). Census of population and housing-2012 (New) - Final report. Colombo: Department of Census and Statistics. Retrieved December 20, 2014 from http://www.statistics.gov.lk/PopHouSat/CPH2012Visualization/htdocs/index.php ?usecase=indicator\&actio $\mathrm{n}=$ Map\&indId $=10$

Department of Elections. (1988). Result of the presidential election 1988. Colombo: Department of Elections. Retrieved December 20, 2015 from http://52.1.201.50/web/images/pdf/past-presidential-election-results/result-of-presidential-election-1988.pdf

Deshavimala. (2001). Hakeem's new line over his deadline. The Island. 28 January, 2001. Retrieved January 1, 2015, from http://www.island.lk/2001/01/28/defenc02.html

District Secretariat, Amparai. (2013). Annual performance report and budget 2012. Amparai: District Secretariat.

Ibrahim, I. L. M. (2002). Kalmunai coastal district. Sammanthurai: Author's Publication.

Mohideen, M. I. M. (2001). Ethnic conflict and devolution of power in Sri Lanka: Muslim demand separate power-sharing unit in the north-eastern province. Colombo: Muslim National People's Alliance.

Mohideen, M. I. M. (2002). The need for power-sharing arrangements for the Muslims in the north-eastern Sri Lanka. Colombo: Author's Publication.

Mohideen, M. I. M. (2013). Eastern Muslims must unite politically. Colombo: Al-Ceylan Muslim Documentation Center.

Noorul Haque, M.M.M. (2002). Minorities: Some observations. Sainthamaruthu: Marutham Kalai Ilakkiya Vaddam.

Parliament Secretariat. (2011). The Constitution of the democratic socialistic republic of Sri Lanka. Colombo: Parliament of Sri Lanka.

Sahabdeen, M. S. (2015). National issue of Muslims is land and security. Retrieved July 20, 2015 from 
https://www.facebook.com/sahabdeen.meerasahibu/posts/788819104493647:0

Sarjoon, A. (2011). Changing dynamics of minority rights discourse in Sri Lanka's eastern province: A study of the Muslim demand for autonomy. M.Phil Thesis. Colombo: University of Colombo.

Sarjoon, A., Yusoff, M. A., Hussin, N., \& Awang, A. (2015). The demand for an administrative district for the costal belt of Amparai district in Sri Lanka: An assessment of its root causes. Mediterranean Journal of Social Sciences, 6(4S3), 434-443.

Shegu Issadeen, M. H. (2006). Muslim autonomy. Colombo: Muslim Nationalists Movement.

Skynetbit.com. (2005). Mahinda had no plans for Kalmunai coastal district-Hakeem. Retrieved July 10, 2015, from http://skynetbit.blogspot.com/2005/10/mahinda-had-no-plans-for-kalmunai.html

Subramanian, N. (2001). Chandrika's challenge: The People's Alliance coalition government loses its parliamentary majority, leaving Sri Lanka poised on the edge of political uncertainty. Frontline, 18(14). Retrieved January 1, 2015, from http://www.frontline.in/static/html/fl1814/18140530.htm

Yusoff, M. A., \& Sarjoon, A. (2016b). An analysis of the political impacts of establishing the Kalmunai administrative district to the Muslim community in Sri Lanka. Asian Journal of Social Sciences and Humanities, 5(3), 52-66.

Yusoff, M. A., \& Sarjoon, A. (2016a). Communalization of minorities' demands in Sri Lanka: The case of Kalmunai administrative district demand. Journal of Educational and Social Research, 6(3): 99-112.

Yusoff, M. A., Hussin., N., \& Sarjoon, A. (2014). Muslim demand for territorial autonomy in the Eastern Sri Lanka: An analysis of its origin, accommodation and the present stance. Asian Social Science, 10(15), 76-88. http://dx.doi.org/10.5539/ass.v10n15p76

Yusoff, M. A., Sarjoon, A., \& Hassan, M. A. (2016). An analysis of the development impacts of the establishment of Kalmunai administrative district in Sri Lanka. Journal of Sustainable Development, 9(1), 164-174. http://dx.doi.org/10.5539/jsd.v9n1p164

Yusoff, M. A., Sarjoon, A., Awang., A., \& Hamdi, I. H. (2015). Land policies, land-based development programs and the question of minority rights in eastern Sri Lanka. Journal of Sustainable Development, 8(8), 223-233. http://dx.doi.org/10.5539/jsd.v8n8p223

\section{Notes}

Note 1. As part of this study, the criticisms and oppositions expressed to the Kalmunai administrative district demand have also been extensively analyzed. (See: Yusoff and Sarjoon 2016).

Note 2. Originally, the constitutional provision revealed that any party to be elected representatives must secure at least one twelfths of the total valid votes in an electoral district (Parliament Secretariat 2011). At that election, Premadasa won only with the margin of 50.43 percent vote. In all Muslim majority electorates in the north-eastern provinces - the major vote bank of the SLMC, Premadasa received more than 50 percent of votes (See: Department of Elections, 1988).

Note 3. Vanni electoral district covers the 3 administrative districts of northern province namely, Mannar, Vavuniya and Mullaitivu. Similarly, Jaffna electoral districts covers the 2 administrative districts of the northern province namely, Jaffna and Kilinochchi (See: Parliament of Sri Lanka 2011).

\section{Copyrights}

Copyright for this article is retained by the author(s), with first publication rights granted to the journal.

This is an open-access article distributed under the terms and conditions of the Creative Commons Attribution license (http://creativecommons.org/licenses/by/4.0/). 